http://jmscr.igmpublication.org/home/ ISSN (e)-2347-176x ISSN (p) 2455-0450 crossref DOI: https://dx.doi.org/10.18535/jmscr/v8i1.50

\author{
Dournal Of Medical Science And Clinical Research \\ IGM Publication \\ An official Publication of IGM Publication
}

\title{
Primary Squamous Cell Carcinoma of Endometrium in a Postmeno Pausal Female: A Rare Entity
}

\author{
Authors \\ Dr Nisha Attri ${ }^{*}$, Dr Suman Kumari ${ }^{2}$ \\ ${ }^{1}$ Assistant Professor, Department of Pathology, J.N.U Medical College and Hospital \\ ${ }^{2}$ Senior Resident, Department of Pathology, J.N.U Medical College and Hospital \\ *Correspondence Author \\ Dr Nisha Attri
}

\section{Introduction}

Primary squamous cell carcinoma (SCC) of endometrium is very rare. About 70 cases have been reported ${ }^{1}$ so far. It is histologically composed of squamous cells of varying degree of differentiation $^{1}$. Recently, case reports of endometrial SCC have been sporadically published $^{1-6}$. However, the frequency of SCC of the endometrium is unknown. We hereby investigated the frequency at our institution and report a case of endometrial squamous cell carcinoma.

\section{Case Report}

A 67 years old postmenopausal woman presented with chief complaints of vaginal bleeding and abdominal pain since 2 months, following which she was admitted to our hospital on 9 July 2019. Examination revealed pyometra and cervical stenosis. A dilatation and curettage with cervical biopsy was done and sent for histopathological examination. It was reported as chronic non specific cervicitis. Radiological investigations were done in view of persisiting symptoms. Ultrasonography revealed a large mixed echogenic area measuring $50 \times 45 \mathrm{~mm}$ in the uterine wall. The patient underwent radical hysterectomy with bilateral salpingooophorectomy,

Macroscopically, the uterus measured $7 \times 5 \times 3$ $\mathrm{cm}$, and the cervix was $3 \mathrm{~cm}$ long with an outer diameter of $2 \mathrm{~cm}$. The endometrium was $0.1-0.2$ $\mathrm{cm}$ thick, with a grey white area covering $5 \times 3.5$ $\mathrm{cm}$, and infiltrating into the uterine wall. The uterine wall was about $3.5 \mathrm{~cm}$ thick, with several nodules $0.5-3.5 \mathrm{~cm}$ in diameter in the section of the wall, with slightly harder grey and white matter. Histopathological examination confirmed a well differentiated squamous cell carcinoma. The full-thickness of the uterine wall showed tumor invasion. The tumor infiltrated into the mucosa and stroma of the inner cervical canal. The cervix showed mild chronic inflammation, with dysplastic squamous epithelium.

\section{Discussion}

Primary squamous cell carcinoma of the endometrium, is diagnosed only if there is no coexisting analogous cervical component or endometrial adenocarcinoma. There must also be 
no connection between the endometrial tumour and the squamous epithelium of the cervix. The present case was pure squamous cell carcinoma of the endometrium. The uterine cervix was free of tumor. There was no endometrioid adenocarcinoma element in the present tumor. Thus, the present case fulfills the criteria of primary squamous cell carcinoma of the endometrium $^{1}$. (Figure-1-3)

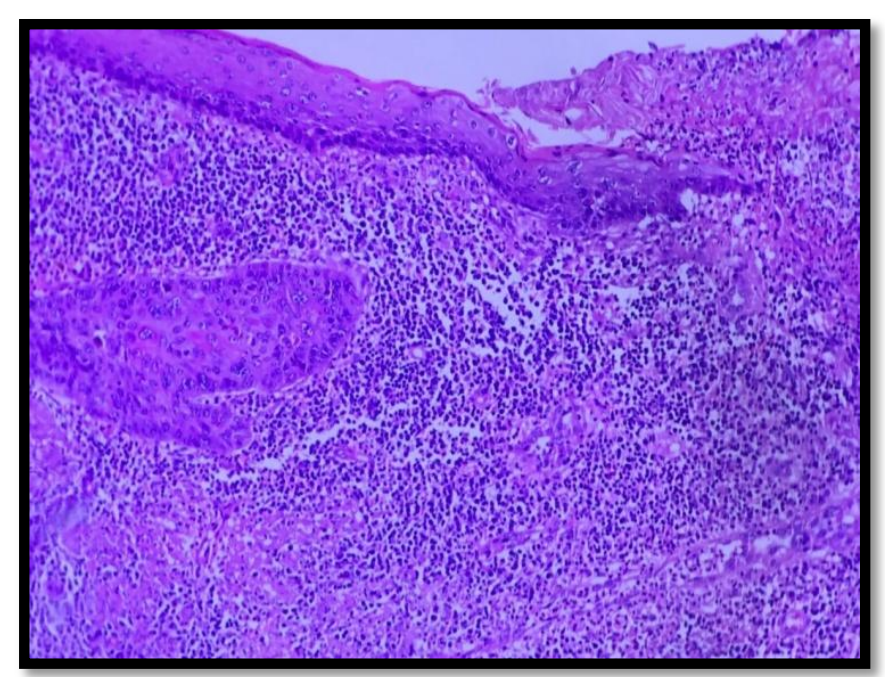

Figure-1 Normal squamous epithelium of the ectocervix. There was no connection between the endometrial tumour and the squamous epithelium of the cervix.

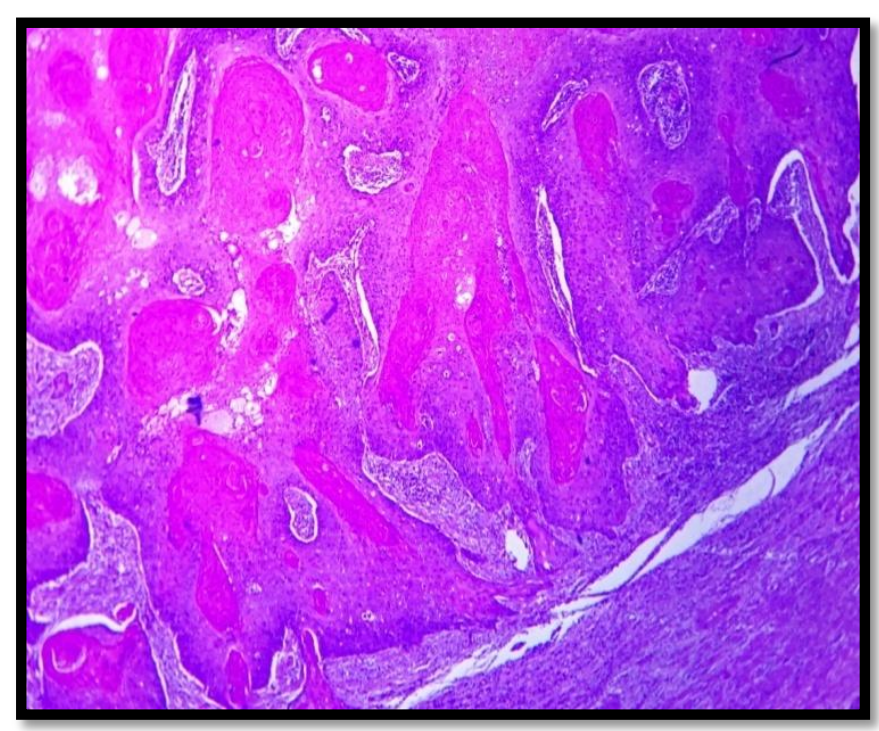

Figure-2 Well differentiated Squamous cell carcinoma of the endometrium (H \& E X 40)

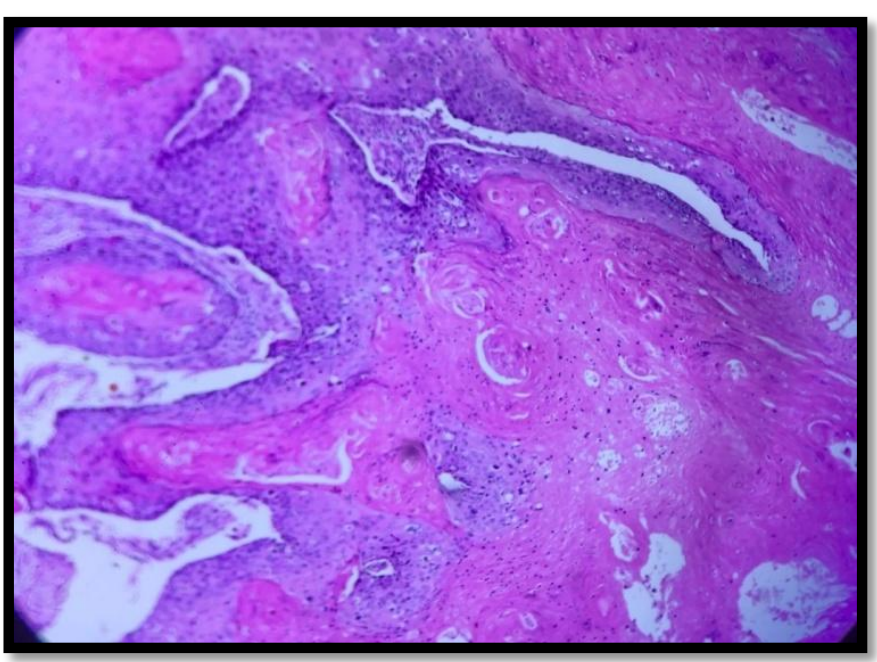

Figure 3 Well differentiated Squamous cell carcinoma of the endometrium (H \& E X 100)

Primary squamous cell carcinoma of the endometrium has been reported to show poorer prognosis than endometrioid carcinoma ${ }^{1,3,5}$. The prognosis depends mainly on tumor stage. The pathogenesis is unknown. Several possibilities exist. First, the squamous cell carcinoma is a complete malignant squamous differentiation of endometrioid adenocarcinoma. Second, HPV is involved in the pathogenesis of primary squamous cell carcinoma of the endometrium ${ }^{4,6}$. Thirdly, squamous metaplasia-dysplasia- squamous cell carcinoma sequence is involved in the pathogenesis of primary squamous cell carcinoma of the endometrium. ${ }^{6}$ Finally, primary squamous cell carcinoma of the endometrium may develop from ectopic cervical tissue in the endometrium.$^{2}$ In the present study, there was no ectopic cervical tissue, squamous metaplasia, or dysplaia. HPV was not investigated in the present study. Much more studies are required to determine the pathogenesis of primary squamous cell carcinoma of the endometrium.

\section{Conclusion}

Primary squamous cell carcinoma is a rare type of endometrial carcinoma with an unclear etiology. The current case report indicated that it can occur in postmenopausal women, though its pathogenesis and therapeutic regimen remain controversial. Surgery combined with 
radiochemotherapy is considered to be the optimal therapy. Biological targeted therapy is also developing rapidly, and we suggest that combined biological therapy may further improve the adverse prognosis of primary squamous cell carcinoma of the endometrium.

\section{References}

1. Silverberg SG, Kurman RJ, Nogales F, Mutter GL, Kubik-Huch RA, Tavassoli FA. Epitheial tumour and related lesions. In: Tavassoli FA, Devilee P, editors. WHO classification of tumours. Pathology and genetics, Tumours of the breast and female genital organs. Lyon: IARC press; 2003. pp. 221-232.

2. Yamamoto Izumi K, Otsuka H, Kishi Y, Mimura T, Okitsu O. Primary small cell carcinoma of the endometrium: a case report and a suggestion of new histogenesis. Int $\mathrm{J}$ Gynecol Pathol. 1995;14:75-80.

3. Kennedy AS, Demars LR, Flannagan LM, Varia MA. Primary squamous cell carcinoma of the endometrium: a first report of adjuvant chemoradiation. Gynecol Oncol. 1995;59:117-123.

4. Im DD, Shah KV, Rosenshein NB. Report of three cases of squamous carcinoma of the endometrium with emphasis in the HPV status. Gynecol Oncol. 1995;56:464469.

5. Goodman A, Zukerberg LR, Rice LW, Fuller AF, Young RH, Scully RE. Squamous cell carcinoma of the endometrium: A report of eight cases and a review of the literature. Gynecol Oncol. 1996;61:54-60.

6. Kataoka A, Nishida T, Sugiyama T, Hori K, Honda S, Yakashiji M. Squamous cell carcinoma of the endometrium with human papilloma virus 31 and without tumor suppressor gene p53 mutation. Gynecol Oncol. 1997;65:180-184. 